\title{
PHYTOCHEMICAL AND ANTIOXIDANT PROPERTIES OF TRADITIONALLY USED MISTLETOES IN NEPAL
}

\author{
Kranti Kumal", Deepak Raj Pant", Biva Aryal ${ }^{* * * * * *}$, Giri Raj Tripathi ${ }^{* * * * *}$ and Giri Prasad Joshi* \\ ${ }^{*}$ Central Department of Botany, Tribhuvan University, Kathmandu, Nepal. \\ ${ }^{* *}$ Amrit Campus, Tribhuvan University, Kathmandu, Nepal. \\ ${ }^{* * *}$ Society of Natural Resource Conservation and Development, Kathmandu, Nepal. \\ ${ }^{* * * *}$ Central Department of Biotechnology, Tribhuvan University, Kathmandu, Nepal.
}

\begin{abstract}
Mistletoes are being used for food or beverage and for variety of medicinal purposes. In Nepal, mistletoes are traditionally used as fodder and as remedy to cure various ailments. In this study, methnolic extracts of seven common mistletoe species (Helixanthera ligustrina, Macrosolen cochinchinensis, Scurrula elata, S. parasitica, Viscum album, V. articulatum and $V$. liquidambaricola) were analyzed for their phytochemical constituents and antioxidant potential. The total flavonoid content (TFC) and total phenol content (TPC) were quantitatively determined by aluminum chloride colorimetric and folin-cioalteau reagent methods, respectively. The TFC was found highest for V. album (31.5 $\pm 2.3 \mathrm{mg}$ $\mathrm{QE} / \mathrm{g})$ and lowest for $M$. cochinchinensis $(24.9 \pm 2.3 \mathrm{mg}$ QE/g). Similarly, highest total phenolic content was found in $S$. parasitica $(32.9 \pm 2.5 \mathrm{mg} \mathrm{GAE} / \mathrm{g})$ and lowest in $V$. album $(20.6 \pm 2.1 \mathrm{mg} \mathrm{GAE} / \mathrm{g})$. The antioxidant activity measured by DPPH radical scavenging assay was found best for $S$. parasitica (with lowest $\mathrm{IC}_{50}$ value; $26.0 \pm 0.7 \mu \mathrm{g} / \mathrm{ml}$ ) among the studied mistletoes. Overall analysis provides scientific evidence in favor of indigenous use of these mistletoes as a source of fodder, food and for medicinal purposes.
\end{abstract}

Keywords: Mistletoes; Phenolic content; Flavonoid content; Antioxidant activity.

\section{INTRODUCTION}

Mistletoes are highly specialized flowering plant of sandalwood family (Order; Santalales), that exploit and (or) parasitize a wide range of host plants ${ }^{1,2,3}$. Altogether, 1500 species of mistletoes are known worldwide ${ }^{4}$.They are occasionally used as food or beverage and also for variety of medicinal purposes for humans and animals to cure muscular swelling, sprains, fractures and dislocations ${ }^{1,5}$. In Africa, mistletoes are used in treatment of various stomach troubles of children including diarrhea, hypertension, diabetes, and schizophrenia and also used as an immune system booster ${ }^{6}$. Similarly, the people of ancient Greek and Argentina uses these plants in spleen diseases and for problems related to menstruation, respectively. However,
Indian people used mistletoes as a tea against diabetes ${ }^{7}$.

Mistletoes like V. album ${ }^{8,9}$, Taxillus yadoriki, T. kaempferi and Korthalsella japonica ${ }^{10}$, Loranthus parasiticus ${ }^{11}$, species of Scurrula and Viscum ${ }^{12}$ and L. micranthus ${ }^{13}$ were phytochemically explored and found to contain different chemicals of medicinal importance. Similarly, few mistletoe species such as S. ferruginea ${ }^{14}$, L. micranthus ${ }^{15}$, L. parasiticus $^{11}$, L. europaeus ${ }^{16}$, L. regularis ${ }^{17}$, V. album $^{18}$, and Dendrophthoe pentandra ${ }^{19}$ were assayed for their antioxidant properties.

Among the 19 species of mistletoes found in Nepal some are being used traditionally by indigenous people since long but remained unused by the modern pharmacological practice. Mistletoes like Dandrophthoe falacata, V. album

Author for correspondence: Giri Prasad Joshi, Central Department of Botany, Tribhuvan University, Kathmandu.

Email: giri.joshi@cdb.tu.edu.np

Received: 28 Aug 2020; Review: 27 Sep 2020; Accepted: 30 Sep 2020.

Doi: https://doi.org/10.3126/sw.v14i14.34999 
and $V$. articulatum were reported to be used by indigenous people of Nepal ${ }^{20}$. Similarly, 11 species of mistletoes and their uses by peoples of Bardia (tropical region) and Godawari-Phulochoki area (temperate region) have been documented $^{5}$. The recent study also included the information of indigenous use of 15 mistletoes from different parts of the country ${ }^{21}$. Present study aimed to analyze phytochemical constituents and antioxidant potential of common mistletoes of Kathmandu valley which were already been documented for their indigenous use by previous researchers.

\section{MATERIALS AND METHODS}

Collection and identification of plant samples

Different species of mistletoes were collected from surroundings of Kathmandu valley (Table 1). The specimens were identified with the help of "Flora of Kathmandu Valley" and then cross checked with specimen deposited at National Herbarium and Plant Laboratories (KATH). Collected specimen were dried and fixed in herbarium sheet and deposited at Tribhuvan University Central Herbarium (TUCH).

\section{Preparation and extraction of plant material}

The collected plant materials were air/shade dried at 32$35^{\circ} \mathrm{C}$ for 6 days to remove moisture and powdered. Fifteen grams of fine powder of each plant sample was weighed separately and dissolve in $150 \mathrm{ml}$ of $100 \%$ methanol (Thermo Fisher Scientific, India). The mixtures were placed in Sonicator (UC-7240BDT E-Chrome Tech, Taiwan) using ultrasonic wave at $40 \mathrm{~Hz}$ for 2 hours and then filtered using Whatman No. 1 filter paper. The step was repeated with the residue for complete extraction. Then the filtrate recovered from both steps was allowed to evaporate under reduced pressure until completely dry and form solid mass (waxy). Obtained solid mass was weighed to express the gram of extract extracted per 15 grams of the plant powder. For each sample, extract was prepared individually and kept at $4^{0} \mathrm{C}$ for further use. Finally, 100mg of crude plant extract dissolved in $1 \mathrm{ml}$ methanol was used for quantification of total phenol, total flavonoids, and antioxidant activity.

Table 1. List of plants under study with elevation and parts used Fam. ${ }^{a}$ : Family; Lor: Loranthaceae, Vis: Viscaceae. Ele.

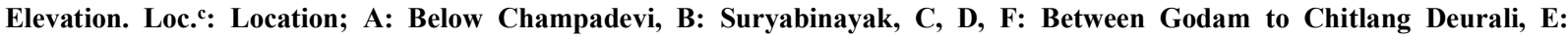
Chitlang Deurali, G: Chitlang. Parts used ${ }^{\mathrm{d}}$ : L: Leaf, YL: Young Leaf, WP: Whole Plant

\begin{tabular}{|c|c|c|c|c|c|c|c|}
\hline S.N & Mistletoe Species & Acronyms & Fam. $^{a}$ & Ele. ${ }^{\mathrm{b}}(\mathrm{m})$ & Host species & Loc. $^{c}$ & $\begin{array}{l}\text { Parts } \\
\text { used }^{\mathrm{d}}\end{array}$ \\
\hline 1 & $\begin{array}{l}\text { Helixanthera ligustrina } \\
\text { (Wall.) Danser }\end{array}$ & HLI & Lor & 1690 & $\begin{array}{l}\text { Pyrus pashia Buch.- } \\
\text { Ham. ex D. Don }\end{array}$ & A & $\mathrm{L}$ \\
\hline 2 & $\begin{array}{l}\text { Macrosolen cochin- } \\
\text { chinensis (Lour.) Tiegh. }\end{array}$ & $\mathrm{MCO}$ & Lor & 1667 & Schima wallichi Choisy & $\mathrm{B}$ & YL \\
\hline 3 & $\begin{array}{l}\text { Scurrula elata (Edgew.) } \\
\text { Danser }\end{array}$ & SEL & Lor & 2000 & $\begin{array}{l}\text { Myrica esculenta } \\
\text { Buch.-Ham. ex D. Don }\end{array}$ & $\mathrm{C}$ & $\mathrm{L}$ \\
\hline 4 & Scurrula parasitica L. & SPA & Lor & 1933 & $\begin{array}{l}\text { Pyrus pashia Buch.- } \\
\text { Ham. ex D. Don }\end{array}$ & $\mathrm{D}$ & $\mathrm{L}$ \\
\hline 5 & Viscum album L. & VAL & Vis & 2102 & $\begin{array}{l}\text { Prunus cerasoides } \\
\text { Buch.-Ham. ex D. Don }\end{array}$ & $\mathrm{E}$ & WP \\
\hline 6 & $\begin{array}{l}\text { Viscum articulatum } \\
\text { Burm. f. }\end{array}$ & VAR & Vis & 2484 & $\begin{array}{l}\text { Quercus semecarpifolia } \\
\text { Sm. }\end{array}$ & $\mathrm{F}$ & WP \\
\hline 7 & $\begin{array}{l}\text { V. liquidambaricola } \\
\text { Hayata }\end{array}$ & VLI & Vis & 2300 & $\begin{array}{l}\text { Betula alnoides Buch.- } \\
\text { Ham. ex D. Don }\end{array}$ & G & WP \\
\hline
\end{tabular}




\section{Total flavonoid content (TFC)}

The TFC was determined by using the aluminum chloride colorimetric method with slight modification ${ }^{22} .0 .25 \mathrm{ml}$ of extract $(10 \mathrm{mg} / \mathrm{ml})$ was separately mixed with the $0.75 \mathrm{ml}$ of ethanol, $0.05 \mathrm{ml}$ of the $10 \%$ aluminum chloride, $0.05 \mathrm{ml}$ of the $1 \mathrm{M}$ potassium acetate and $1.4 \mathrm{ml}$ of the distilled water. The solution mixture was shaken and allowed to stand at room temperature for 30 minutes. The absorbance of the reaction mixture was measured at $415 \mathrm{~nm}$ using UV-visible spectrophotometer (CT8600, E-Chrome Tech, Taiwan). Quercetin was used as standard solution in methanol with the concentration ranging from 10-100 $\mu \mathrm{g} / \mathrm{ml}$. and blank was prepared by adding all the reagents except the plant sample. The TFC was expressed in terms of milligram Quercetin per gram of dry mass (mg QE/g).

Total phenolic content (TPC)

The TPC was determined by folin-ciocalteau method ${ }^{23}$ with slight modification by mixing $0.1 \mathrm{ml}$ of the sample extracts $(2.5 \mathrm{mg} / \mathrm{ml})$ with $1 \mathrm{ml}$ folin-ciocalteau reagent (1:10 dilution with distilled water) and $0.8 \mathrm{ml}$ of aqueous $1 \mathrm{M}$ sodium carbonate. The reaction mixture was left for 15 minutes and absorbance was measured at $765 \mathrm{~nm}$. A calibration curve was obtained using Gallic acid in methanol using the concentration ranging from $25-250$ $\mu \mathrm{g} / \mathrm{ml}$ as standard. Based on the standard curve, the concentration of each sample was calculated. The TPC content was expressed in terms of the milligram of the Gallic acid equivalent per gram of the dry mass (mg $\mathrm{GAE} / \mathrm{g})$.

\section{Antioxidant activity assay}

Antioxidant activity of the plant extract was determined through the DPPH (2,2-Diphenyl-1-picrylhydrazyl; Fisher Scientific India Limited) free radical scavenging activity using ascorbic acid standard ${ }^{24}$. The different concentration of plant extract $(25-200 \mu \mathrm{g} / \mathrm{ml})$ and ascorbic acid (10-100 $\mu \mathrm{g} / \mathrm{ml}$ ) were prepared in methanol. $0.5 \mathrm{ml}$ of samples of plant extract as well as ascorbic acid of each concentration was taken separately in clean test tubes. Then $0.5 \mathrm{ml}$ of DPPH solution $(0.2 \mathrm{mM})$ was added, properly mixed and incubated in dark for 30 minutes. The controls were prepared as above but without plant extract or ascorbic acid. Absorbance of the solution was measured at $517 \mathrm{~nm}$.

The free radical scavenging activity (RSA) of plant samples was calculated as follows and expressed in percentage: \% Radical Scavenging activity $(\mathrm{RSA})=100 *$ Abs. control-Abs. sample/Abs. control.

\section{Statistical analysis}

All the experiments were performed in triplicates (mean \pm SD) and the data obtained were analyzed in Microsoft excel 2010.

\section{RESULTS}

\section{Total flavonoid content (TFC)}

Quercetin was used as standard to determine TFC in plant extracts. The equation obtained from graph of Quercetin was used for the estimation of TFC expressed in terms of $\mathrm{mg} \mathrm{QE} / \mathrm{g} \pm \mathrm{SD}$. The highest TFC was estimated as $31.5 \pm$ $2.3 \mathrm{mg} \mathrm{QE} / \mathrm{g}$ for $V$. album and lowest as $24.9 \pm 2.3 \mathrm{mg}$ $\mathrm{QE} / \mathrm{g}$ for $M$. cochinchinensis. The amount of TFC in rest of the species lied between these two extremes (Figure 1).

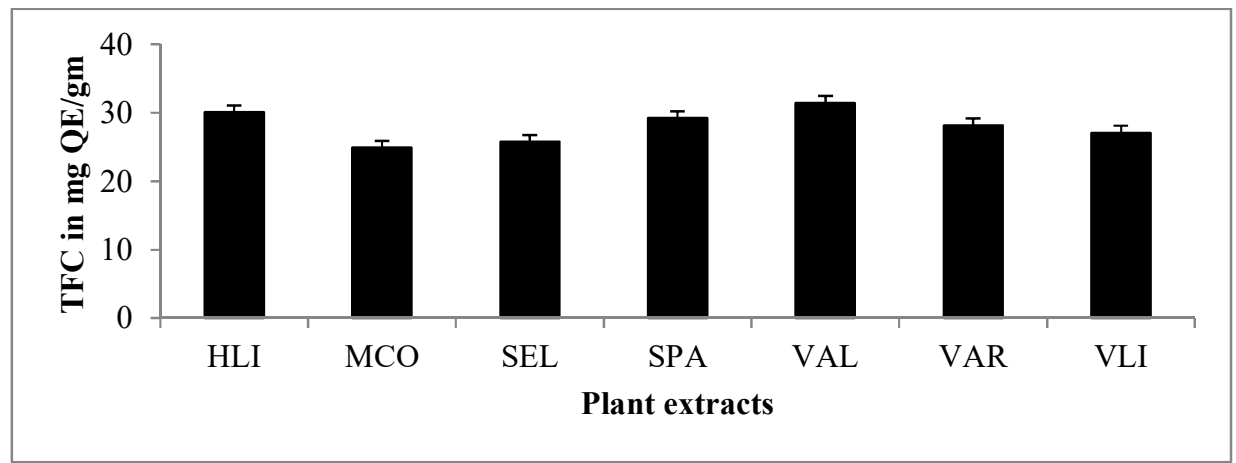

Figure 1: Total flavonoid content present in different mistletoes. Error bar indicate $\pm S D(N=3)$.

Legend: HLI: Helixanthera ligustrina, MCO: Macrosolen cochinchinensis, SEL: Scurrula elata, SPA: Scurrula parasitica, VAL: Viscum album, VAR: Viscum articulatum, VLI: Viscum liquidambaricola. 
Total phenolic content (TPC)

Based on the equation of Gallic acid, total phenolic content present in methanolic extract of seven different samples was determined. The highest amount of TPC was found in $S$. parasitica $(32.9 \pm 2.5 \mathrm{mg} \mathrm{GAE} / \mathrm{g})$ while lowest found in $V$. album $(20.6 \pm 2.1 \mathrm{mg} \mathrm{GAE} / \mathrm{g})$, rest of the species possessed the amount lies between two values (Figure 2).

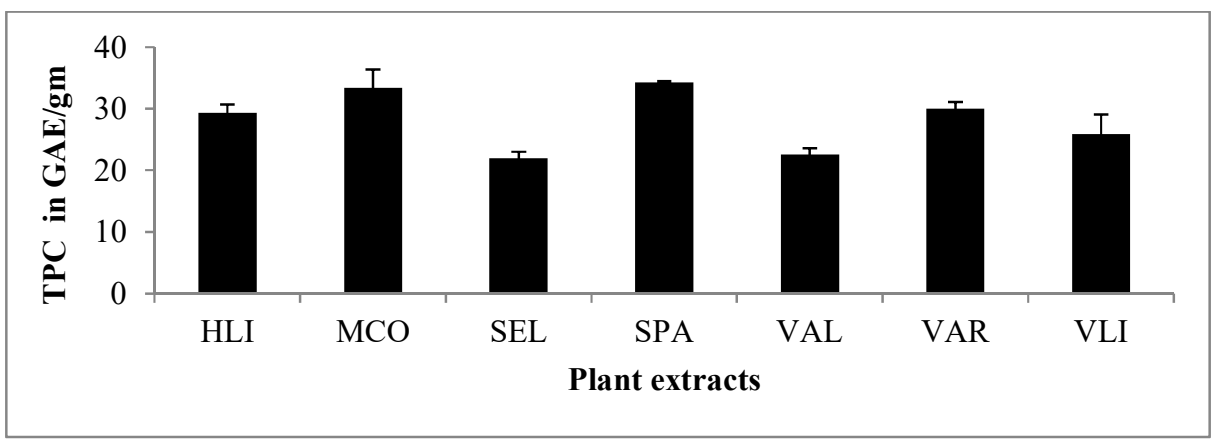

Figure 2: Total phenolic content present in different mistletoes. Error bar indicate $\pm \mathbf{S D}(\mathbf{N}=\mathbf{3})$.

Legend: HLI: Helixanthera ligustrina, MOCO: Macrosolen cochinchinensis, SEL: Scurrula elata, SPA: Scurrula parasitica, VAL: Viscum album, VAR: Viscum articulatum, VLI: Viscum liquidambaricola.

\section{Antioxidant activity of the plant extract}

In this study, DPPH was used as the source of free radical and ascorbic acid as pure antioxidant reference compound. There was gradual increase in percentage radical scavenging activity as the concentration of extract increased (data not shown). The $\mathrm{IC}_{50}$ value for ascorbic acid was measured as $19.61 \mu \mathrm{g} / \mathrm{ml}$ while for plant extracts, highest and lowest $\mathrm{IC}_{50}$ values were obtained for $V$. album $(199.0 \pm 1.3 \mu \mathrm{g} / \mathrm{ml})$ and $S$. parasitica $(26.0 \pm 0.7 \mu \mathrm{g} / \mathrm{ml})$, respectively. The $\mathrm{IC}_{50}$ value of $S$. parasitica showed best antioxidant activity which is more or less comparable to the standard i.e. ascorbic acid. Three mistletoe species; $M$. cochinchinensis $(65.9 \pm 2.8 \mu \mathrm{g} / \mathrm{ml})$, H. ligustrina $(88.2 \pm$ $0.7 \mu \mathrm{g} / \mathrm{ml})$ and $V$. liquidambaricola $(102.6 \pm 3.8 \mu \mathrm{g} / \mathrm{ml})$ showed moderate antioxidant activity as compared to $S$. parasitica. Similarly, S. elata $(186.4 \pm 6.5 \mu \mathrm{g} / \mathrm{ml}), V$. album $(199.0 \pm 1.3 \mu \mathrm{g} / \mathrm{ml})$, and $V$. articulatum $(183.1 \pm 0.6$ $\mu \mathrm{g} / \mathrm{ml})$ were found to show least antioxidant activity (Figure 3).

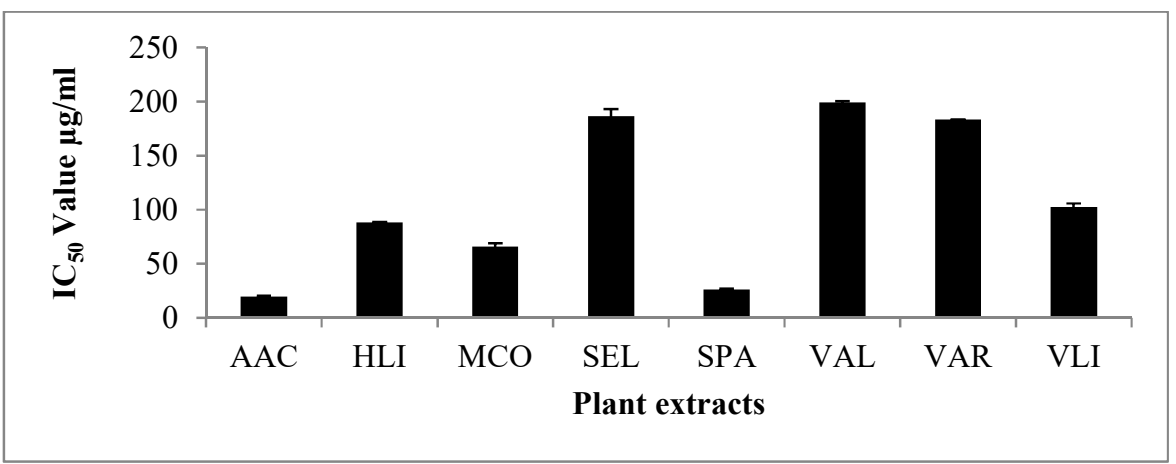

Figure 3: $\mathrm{IC}_{50}$ value of different mistletoe species (AAC: Ascorbic acid). Error bar indicate $\pm \mathrm{SD}$ (N=3).

Legend: HLI: Helixanthera ligustrina, MCO: Macrosolen cochinchinensis, SEL: Scurrula elata, SPA: Scurrula parasitica, VAL: Viscum album, VAR: Viscum articulatum, VLI: Vicum liquidambaricola.

\section{DISCUSSION}

Secondary metabolites are the chemicals developed in plants for self-defense from environmental stress, animals and plants including microorganisms. Among the secondary metabolites, flavonoids are a class of secondary plant phenolics with significant antioxidant and chelating 
property $^{25}$. In this study, the TFC varies from $24.9 \mathrm{mg}$ $\mathrm{QE} / \mathrm{g}$ to $31.5 \mathrm{mg} \mathrm{QE} / \mathrm{g}$. The TFC in M. cochinchinensis (24.9 mg QE/g) of present study showed similarity with the value reported in the earlier work ${ }^{26}$ on $M$. parasiticus (22.5 mg QE/g). Similarly, in an another work ${ }^{27}$, TFC was reported for Dendrophthoe falcata as 5.0, 9.0 and $15.0 \mathrm{mg}$ $\mathrm{QE} / \mathrm{g}$ for chloroform, methanol and hydroalcoholic extracts, respectively. These amounts were distinctly less than the amount of TFC of mistletoes in present study. These variations may be due to difference between the species and type of solvent used for extraction.

The amount of TPC obtained from methanolic extract of leaves of $S$. parasitica was higher than the amount reported by earlier researchers ${ }^{28}(21.77 \pm 1.41 \mathrm{mg} \mathrm{GAE} / \mathrm{g})$. However, highest amount of TPC was reported from ethanolic extracts of $S$. parasitica $(210 \mathrm{mg} \mathrm{GAE} / \mathrm{g})$ and $M$. cochinchinensis (150 mg GAE/g) using high temperature batch extraction method ${ }^{29}$. Similarly, variable amount of TPC has been reported for acetone extracts of Scurrula ferruginea $^{14}$. The highest amount was obtained in stem $(309.1 \pm 1.2 \mathrm{mg} \mathrm{GAE} / \mathrm{g})$ followed by leaf $(144.2 \pm 0.7 \mathrm{mg}$ GAE/g) and flower (126.4 $\pm 0.3 \mathrm{mg} \mathrm{GAE} / \mathrm{g})$. Furthermore, methanolic extracts of $V$. album grown on two different host trees was examined for TPC using tannic acid as standard compounds. $V$. album grew on Cocoa tree possessed higher TPC (182 mg/100g) than Cashew tree $(160 \mathrm{mg} / 100 \mathrm{~g})^{30}$. The lower total phenolic content in seven mistletoe species of present study may be due to the use of different plant parts for extraction, type of solvent in which extraction was performed and even type of host trees on which mistletoes grew.

Antioxidants derived from natural resources mainly from plants have been intensively used to prevent oxidative damages $^{31}$. So the antioxidant properties of plant extract are very important for investigation of their pharmaceutical uses. Antioxidant property can be concluded on the basis of \% radical scavenging activity (RSA) and $\mathrm{IC}_{50}$ value. Antioxidant activity of the plant extract is expressed as percent inhibition of stable free radical or inhibition concentration fifty $\left(\mathrm{IC}_{50}\right)$ in reference to a standard compound. The plant with higher percentage
RSA and corresponding lowest $\mathrm{IC}_{50}$ value is considered having better antioxidant properties. The higher $\mathrm{IC}_{50}$ value $(110.91 \mu \mathrm{g} / \mathrm{ml})$ for methanolic extracts of $S$. parasitica than the present study $(26.0 \pm 0.7 \mu \mathrm{g} / \mathrm{ml})$ has been reported earlier ${ }^{32}$. Much higher $\mathrm{IC}_{50}$ value $(599.6 \mu \mathrm{g} / \mathrm{ml})$ for methanolic extract of $M$. cochinchinensis was also reported $^{33}$. The difference between the values obtained in present and previous studies may be due plant collection from different geographical locations and extraction process. In both studies, plants were collected from tropical climatic condition and used simple extraction procedure compared to the present study (temperate climatic condition and sonication method). The present finding is again supported by the previous work ${ }^{34}$ where antioxidant potential was found increased with the rising altitude.

\section{CONCLUSION}

Present study attempted to explore phytochemical constituents and antioxidant potentialities of 7 mistletoes commonly available in surrounding mountains of Kathmandu valley. Overall analysis of phytochemical constituents and antioxidant activity suggested that all mistletoes traditionally been used for different purposes were rich in terms of different phytochemicals. Among the selected species, five species (H. ligustrina, $M$. cochinchinensis, $\quad V$. album, $V$. articulatum, $V$. liquidambaricola) were used for medicinal purposes and two ( $S$. elata, $S$. parasitica) as fodder by indigenous people of Nepal. Quantitative estimation of TPC and TFC also deduced that the selected mistletoes are rich in both phytochemicals. However, antioxidant potential of $S$. parasitica was found best among all, although traditionally been used as fodder and ignored for its medicinal importance.

\section{ACKNOWLEDGEMENT}

The authors are grateful to the Cornell Nepal Study Program (CNSP) for providing partial financial support to carry out this research work.

\section{REFERENCES}

1. Mathiasen, R. L., Nickrent, D. L., Shaw, D. C., Watson, D. M. 2008. Mistletoes: pathology, systematics, ecology, and management. Plant Disease. 92(7): 988-1006. 
2. Joshi, G. P., Devkota, M. P. 2010. Diversity, host range and distribution of mistletoes along steep altitudinal gradient of Tribhuvan highway, Central Nepal. Our Nature. 8: 106-117.

3. Devkota, M.P., Joshi, G.P., Parajuli, P. 2011. Diversity, distribution and host range of mistletoe in protected and unprotected areas of Central Nepal Himalayas. Banko Jankari. 20(2): 14-20.

4. Nickrent, D. L. 2011. Santalales (including mistletoes). John Wiley \& Sons Ltd.

5. Kunwar, R.M., Adhikari, N., Devkota, M.P. 2005. Indigenous use of mistletoes in tropical and temperate region of Nepal. Banko Jankari. 15: 38-42.

6. Moghadamtousi, S. Z., Hajrezaei, M., Abdul Kadir, H., Zandi, K. 2013. Loranthus micranthus Linn.: Biological activities and phytochemistry. Evidence Based Complemen-tary and Alternative Medicine. Article ID 273712, 9 pages.

7. Bussing, A. 2003. Mistletoe: the genus Viscum. CRC Press.

8. Kusi, M., Shrestha, K., Malla, R. 2015. Study on phytochemical, antibacterial, antioxidant and toxicity profile of Viscum album Linn associated with Acacia catechu. Nepal Journal of Biotechnology. 3(1): $60-65$.

9. Oguntoye, S. O., Olatunji, G. A., Kolawole, O. M., Enonbun, K. I. 2008. Phytochemical screening and antibacterial activity of Viscum album (Mistletoe) extracts. Plant Sciences Research. 1(3): 44-46.

10. Fukunaga, T., Nishiya, K., Kajikawa, I., Takeya, K., Itokawa, H. 1989. Studies on the constituents of Japanese mistletoes from different host trees, and their antimicrobial and hypotensive properties. Chemical and Pharmaceutical Bulletin. 37(6): 15431546.

11. Moghadamtousi, S. Z., Kamarudin, M. N. A., Chan, C. K., Goh, B. H., Kadir, H. A. 2014. Phytochemistry and biology of Loranthus parasiticus Merr., a commonly used herbal medicine. The American Journal of Chinese Medicine. 42: 23-35.

12. Lim, Y. C., Rajabalaya, R., Lee, S. H. F., Tennakoon, K. U., Le, Q. V., Idris, A., David, S. R. 2016. Parasitic mistletoes of the genera Scurrula and Viscum: from bench to bedside. Molecules. 21(8): 1048.

13. Cemaluk, E. A., Nwankwo, N. E. 2012. Phytochemical properties of some solvent fractions of petroleum ether extract of the African mistletoe (Loranthus micranthus Linn.) leaves and their antimicrobial activity. African Journal of Biotechnology. 11(62): 12595-12599.

14. Marvibaigi, M., Amini, N., Supriyanto, E., Jamil, S., Majid, F. A. A., Khangholi, S. 2014. Total phenolic content, antioxidant and antibacterial properties of Scurrula ferruginea extracts. Jurnal Teknologi. 70(5): 65-72.

15. Agbo, M. O., Lai, D., Okoye, F. B., Osadebe, P. O., Proksch, P. 2013. Antioxidative polyphenols from Nigerian mistletoe Loranthus micranthus (Linn.) parasitizing on Hevea brasiliensis. Fitoterapia. 86: 78-83.
16. Katsarou, A., Rhizopoulou, S., Kefalas, P. 2012. Antioxidant potential of the aerial tissues of the mistletoe Loranthus europaeus Jacq. Records of Natural Products. 6(4): 394-397.

17. Mothana, R. A., Al-Said, M.S., Al-Rehaily, A.J., Thabet, T. M., Awad, N. A., Lalk, M., Lindequist, U. 2012. Anti-inflammatory, antinociceptive, antipyretic and antioxidant activities and phenolic constituents from Loranthus regularis Steud. ex Sprague. Food Chemistry. 130(2): 344-349.

18. Vicas, S., Prokisch, J., Rugina, D., Socaciu, C. 2009. Hydrophilic and lipophilic antioxidant activities of Mistletoe (Viscum album) as determined by FRAP method. Notulae Botanicae Horti Agrobotanici Cluj-Napoca. 37(2): 112-116.

19. Artanti, N., Firmansyah, T., Darmawan, A. 2012. Bioactivities evaluation of Indonesian mistletoes (Dendrophthoe pentandra (L.) Miq.) Leaves extracts. Journal of Applied Pharmaceutical Science. 2(1): 24-27.

20. HMGN. 1970. Medicinal plants of Nepal. Bulletin of the department of medicinal plants No. 3. Department of plant resources, MoFSC, Kathmandu, Nepal. 153.

21. O’Neill, A. R., Rana, S. K. 2016. An ethnobotanical analysis of parasitic plants (Parijibi) in the Nepal Himalaya. Journal of Ethnobiology and Ethnomedicine. 12(1). Article number: 14.

22. Chang, C. C., Yang, M. H., Wen, H. M., Chern, J. C. 2002. Estimation of total flavonoid content in propolis by two complementary colorimetric methods. Journal of Food and Drug Analysis. 10(3): 178-182.

23. Ainsworth, E. A., Gillespie, K. M. 2007. Estimation of total phenolic content and other oxidation substrates in plant tissues using Folin-Ciocalteu reagent. Nature Protocols. 2(4): 875-877.

24. Singh, R. P., Chidambara Murthy, K. N., Jayaprakasha, G. K. 2002. Studies on the antioxidant activity of pomegranate (Punica granatum) peel and seed extracts using in vitro models. Journal of Agricultural and Food Chemistry. 50(1): 81-86.

25. Heim, K. E., Tagliaferro, A. R., Bobilya, D. J. 2002. Flavonoid antioxidants: chemistry, metabolism and structure-activity relationships. The Journal of Nutritional Biochemistry. 13(10): 572 584.

26. Lobo, R., Sodde, V., Dashora, N., Gupta, N., Prabhu, K. 2011. Quantification of flavonoid and phenol content from Macrosolen parasiticus (L.) Danser. Journal of Natural Product and Plant Resourses. 11: 96-99.

27. Pattanayak, S. P., Mazumder, P. M., Sunita, P. 2012. Total phenolic content, flavonoid content and in vitro antioxidant activities of Dendrophthoe falcata (Lf) Ettingsh. Research Journal of Medicinal Plant. 6: 136-148.

28. Ali, M. A., Chanu, KH. V., Devi, L. I. 2013. Scurrula parasitica L. A medicinal plant with high antioxidant activity. International Journal of Pharmacy and Pharmaceutical Sciences.5: 34-37.

29. Rahmawati, S. I., Ishimaru, K., Hou, D. X., Hayashi, N. 2014. Antioxidant activity and phenolic content of Mistletoe extracts 
following high-temperature batch extraction. Food Science and Technology Research. 20(2): 201-206.

30. Oluwaseun, A. A., Ganiyu, O. 2008. Antioxidant properties of methanolic extracts of mistletoes (Viscum album) from cocoa and cashew trees in Nigeria. African Journal of Biotechnology. 7(17).

31. Onay-Ucar E., Karagoz, A., Arda, N. 2006. Antioxidant activity of Viscum album ssp. album. Fitoterapia.77: 556-560.

32. Puneetha, G. K., Amruthesh, K. N. 2016. Phytochemical screening and in vitro evaluation of antioxidant activity of various extracts of Scurrula parasitica. International Journal of Pharmacy and Biological Sciences. 6(1): 77-86.

33. Rahman, M. M., Chowdhury, M. A. U., Uddin, M. E., Islam, A. M. T., Hossain, M. A. 2012. Macrosolen cochinchinensis (Lour.): Anti-nociceptive and antioxidant activity. Asian Pacific Journal of Tropical Biomedicine. 2(1): S203-S207.

34. Kishore, G., Ranjan, S., Pandey, A., Gupta, S. 2010. Influence of altitudinal variation on the antioxidant potential of tartar buckwheat of western Himalaya. Food Science and Biotechnology. 19(5): $1355-1363$ 